\title{
Microstructure evolution and joining mechanism of similar- and dissimilar aluminum alloy joints fabricated by various advanced high-speed solid-state joining methods
}

\author{
Shinji KUMAI**, Shinji MURAISHI**, Yohei HARADA** \\ Takaomi ITOI*** and Masakatsu MAEDA ${ }^{* * * *}$ \\ Keywords: dissimilar metal joining; numerical analysis; magnetic pulse welding; explosive welding; friction stir \\ welding
}

\section{1.はじめに}

本解説は，公益財団法人軽金属奨学会の平成 27 年度統合 的先端研究に採択された「種々の先端的高速固相接合法によ り作製したアルミニウム合金同種・異種接合材の組織形成な らびに接合メカニズムの解明」によって得られた研究成果に ついて，その概要をまとめたものである。本研究の目的は, 単独の材料では実現できない物理的特性や力学的特性をもつ 新規アルミニウム合金や，信頼性・耐久性に富むアルミニウ ム構造体を実現するための手法として, 高速固相接合法に着 目し，各種の先端的固相接合法を用いてアルミニウム合金の 同種・異種接合材を作製するとともに, 実験, 構造解析, 数 值解析を駆使した統合的アプローチによって，接合界面にお ける組織形成プロセスならびに接合メカニズムを解明するこ とである。

ここでいう高速固相接合とは，接合に付随した有害現象の 進行を抑制するため，接合プロセスを極めて短時間で完了さ せたり，接合温度を有害現象開始温度以下に抑えたりするこ とを可能とする接合技術を意味している。本研究で得られる 知見は, 近年その重要性がますます高まっている各種製品の マルチマテリアル・マルチコンポーネント化の実現に大きく 貢献するものと期待できる。
本統合的先端研究では, 種々の高速固相接合法に関する研 究実績のある東京工業大学, 千葉大学, 日本大学の 3 つの研 究グループが結束し, 信頼性に富むアルミニウム合金同種・ 異種接合材を実現するための普遍的な指導原理の獲得とそれ による当該研究分野への学術と工業 (実用) 両面からの貢献 を目指して研究に取り組んだ。

東京工業大学グループは，まず，学術的課題への取り組み として，金属板を超高速で傾斜衝突させる衝撃圧接法につい て, 衝撃解析シミュレーションや伝熱シミュレーションを行 い, 接合プロセスや接合界面近傍の温度変化について解析を 行った。さらに爆薬の爆轟や電磁力を駆動力とする衝撃圧接 法によって実際に純アルミニウムやアルミニウム合金と異種 金属 $(\mathrm{Cu}, \mathrm{Fe}$, 鋼等) との接合材を作製し, その組織解析を 行うことによって, 組織形成プロセスならびに接合メカニズ ムを解明した。加えて, 工業的（実用的）課題への取り組み として，新しい固相スタッド接合法によって，アルミニウム 合金と鋼, アルミニウム合金と金属樹脂積層板との接合に取 り組んだ。

千葉大学グループは, 熱処理型アルミニウム合金板の同 種接合, ならびに鋼鈑との異種接合に取り組んだ。熱処理 型アルミニウム合金同士の接合には過剩な熱源による界面 の融合は不適切であるため, 通常機械的な締結や固相接合

*公益財団法人軽金属奨学会平成 27 年度統合的先端研究成果発表会（平成 29 年 11 月 17 日 グランドプリンスホテル高輪）にて発表予定

**東京工業大学 物質理工学院 材料系（†152-8552 東京都目黒区大岡山 2-12-1） Department of Materials Science and Engineering, Tokyo Institute of Technology (2-12-1 Oookayama, Meguro-ku, Tokyo 152-8550) $\quad$ E-mail: kumai.s.aa@m.titech.ac.jp

***千葉大学 工学部 総合工学科機械工学コース (千葉市) Department of Mechanical Engineering, Faculty of Engineering, Chiba University (Chiba-shi, Chiba)

**** 日本大学 生産工学部 機械工学科（習志野市） Department of Mechanical Engineering, College of Industrial Technology, Nihon University (Narashino-shi, Chiba)

受付日：平成29年5月30日＼cjkstart受理日：平成29年7月 18 日 
法が適用されているが，ここでは熱処理型アルミニウム合 金板の高品位な接合を電磁圧接により実施した。実用的に 用いられる2017, 2024, 7075 合金，および6000系アルミニウ ム合金（6061）について，各々の板の同種接合を行い，ま た6061合金においては実用を踏まえ，高張力鋼板との異種 接合を行い，高い接合強度を有する接合板を作製し，TEM， STEMによる詳細な組織観察を行って，その接合メカニズム を明らかにした。

日本大学グループは, 摩擦攪拌接合 (FSW) に取り組ん だ。FSWは難溶接性アルミニウム合金にも適用できる接合 法として広く知られるが，それでも高強度時効硬化型合金の プロセスウィンドウ（PW (Process Window)）は広くない。 高強度を得ようとすればPW内で最低入熱条件となる方案を 選択する必要があり，そのためにはPWの拡張が不可欠であ る。そこで，加熱あるいは冷却機構を内蔵した接合工具を開 発し，発熱と攪找流動を独立させて制御することにより，従 来困難であった接合条件での接合を可能にした。

以下, 各グループの研究内容を紹介し, 統合的先端研究の 実施により得られた成果について総括する。

\section{2. 高速固相接合した同種・異種金属接合界面の 形成過程ならびに接合メカニズムの解明 （東京工業大学グループ）}

爆薬の爆轟や電磁力を用いて金属板を高速傾斜衝突させ, 数マイクロ秒という極短時間で同種・異種金属を高速固相接 合する手法である衝撃圧接について，実験と数值解析の両面 から取り組んで得られた研究成果を紹介する。さらに放電大 電流により数ミリ秒間でスタッドと薄板を強固に接合する固 相スタッド接合法に関する研究成果について述べる。

\section{1 実験ならびに数値解析による同種・異種金属衝撃圧 接界面の解析と接合メカニズムの解明}

2.1. 1 背景と目的

衝撃圧接法とは，金属板同士を電磁力や爆薬の爆轟を利用 して数百〜数千 $\mathrm{m} / \mathrm{s}$ の高速度で傾斜衝突させ, 数〜数十マイ クロ秒という極短時間で強固に接合する手法である。本グ ループでは，これまで様々な同種・異種金属衝撃圧接材の接 合強度と接合界面形態について, 実験と数值解析（シミュ レーション）の両手法を用い研究を行ってきた。実験的アプ ローチでは，高速ビデオカメラによる接合過程のその場観察 を行い，世界で初めて電磁力による接合材の変形挙動ならび に衝撃圧接時の接合界面からのメタルジェット放出の可視 化に成功している ${ }^{1)}$, 2)。また，電磁力や爆薬の爆轟を用いて 種々の金属の同種・異種金属接合を実施し，（1）接合界面に 形成される特徴的な波状界面形態（波長や振幅）の衝突速 度 ·角度依存性，（2）波状界面形態と接合金属の密度差の関 係，（3）放出されたメタルジェットの捕獲とメタルジェット の化学成分の同定，（4）接合界面近傍の硬さ変化と異種金属 界面近傍の濃度変化，（5）接合界面に生成した中間層（アモ ルファスや非平衡金属間化合物等）の構造等を明らかにして いる ${ }^{3)}$-5)

数值解析によるアプローチでは，衝撃圧接機構を明らかに するために, メッシュを使わない衝撃解析手法, すなわち粒 子法の一種である SPH 法（Smoothed Particle Hydrodynamics method）を用いた衝撃シミュレーションを導入し, $\mathrm{Cu} / \mathrm{Ni}$,
$\mathrm{Cu} / \mathrm{Al}, \mathrm{Al} / \mathrm{Fe}$ 接合材をモデルとして, 同種・異種金属板の衝 突現象や衝撃圧接過程をシミュレーションし, 金属表面が超 高速傾斜衝突する際のメタルジェットの放出挙動や衝突点で の波状界面形成挙動を再現することに成功している ${ }^{6), 7) 。 ~}$

さて, 衝撃圧接においては衝突点からメタルジェットが放 出され，これにより清浄化された金属表面同士が高圧力で圧 接される。これにより金属結合が実現し，母材の温度をほと んど上昇させることなく強固な固相接合が達成される。しか し, 瞬間的ではあるが高圧力となる衝突面では急激な温度上 昇が起こるため，接合界面には局所融解領域が生じ，これに より金属の組合せによっては接合界面に沿って脆弱な中間層 が生成し，接合材の機械的，物理的，化学的特性が低下寸る 場合がある。したがって，このような中間層の生成を抑制す るための接合条件の確立は重要な課題である。衝撃圧接にお ける数〜数十マイクロ秒間で起こる高速変形, 急速加熱, 急 速冷却等の挙動を従来の実験的手法によって明らかにするこ とは困難である。よって数值解析によるシミュレーションを 活用し，この問題を克服する必要がある。

本研究は, 接合界面に合金化領域の形成が予測される $\mathrm{Cu} /$ $\mathrm{Ni}$ と中間層の生成が予測される $\mathrm{Cu} / \mathrm{Al}$ の対照的な 2 種類の異 種金属の組合せを供試材として選定し, 数值解析手法と爆発 圧接材の作製とその組織観察等の実験的手法を組み合わせる ことによって，異種金属爆発圧接に打ける接合界面形成メ力 ニズムを明らかにし，異種金属爆発圧接材の接合強度を低下 させる中間層の生成を抑制する方策を見出すことを目的とし ている。

ここで爆発圧接を研究対象としたのは，爆薬の爆轟を駆 動力とする爆発圧接には電磁力を駆動力とした圧接に比 べ，(1）衝突速度と衝突角度が一定の条件で傾斜衝突が起こ る，（2）大きな波状界面が形成する，（3）界面での温度上昇 が大きい等の特徴があり, よって, 数值解析による衝撃圧接 過程の再現と実験結果との比較が電磁圧接に比べて容易であ るためである。また， $\mathrm{Cu} / \mathrm{Ni}$ の組合せを用いたのは， $\mathrm{Al} / \mathrm{Al} や$ $\mathrm{Cu} / \mathrm{Cu}$ といった同種金属の接合を模擬するためである。 $\mathrm{Cu}$ と $\mathrm{Ni}$ は全率固溶し，金属間化合物等のような中間層を形成し ない。密度差の小さな金属の組合せは，衝撃圧接においては 同種金属と同様な挙動を示すことが知られている。よって, このような異種金属の組合せを用いることにより，同種金属 の接合では観察することが難しい，接合界面における両金属 成分の混ざり合いや塑性流動，温度履歴に関する情報を得る ことができると考えた。

2.1.2 爆発圧接挙動を再現する解析モデルの考案

爆発圧接挙動の全体を再現し得る数值解析手法はいまだ開 発されていない。そこで, 爆発圧接を, 図1に示すように(I) 爆轟を受けたFlyer plateと Parent plateの衝突過程, (II) メ夕 ルジェットの放出挙動ならびに波状界面の形成過程，（III） 接合界面の昇温過程, (IV) 接合界面の冷却過程, (V) 中 間層の生成過程という5つの過程に分類した。次にこれ ら (I) 〜 (V) の爆発圧接過程を再現するための図 2 に示す 3 つの数值解析モデルを考案した。

すなわち, 爆薬と空気のソルバーにEuler, 板材のソルバー に Lagrangeを用い ${ }^{8)}$ ，それらを連成させた Euler-Lagrange coupling model (Model 1) を考案 L, (I) 爆薬の爆轟と板 材の衝突過程を再現した。この解析により, 界面形態を決 


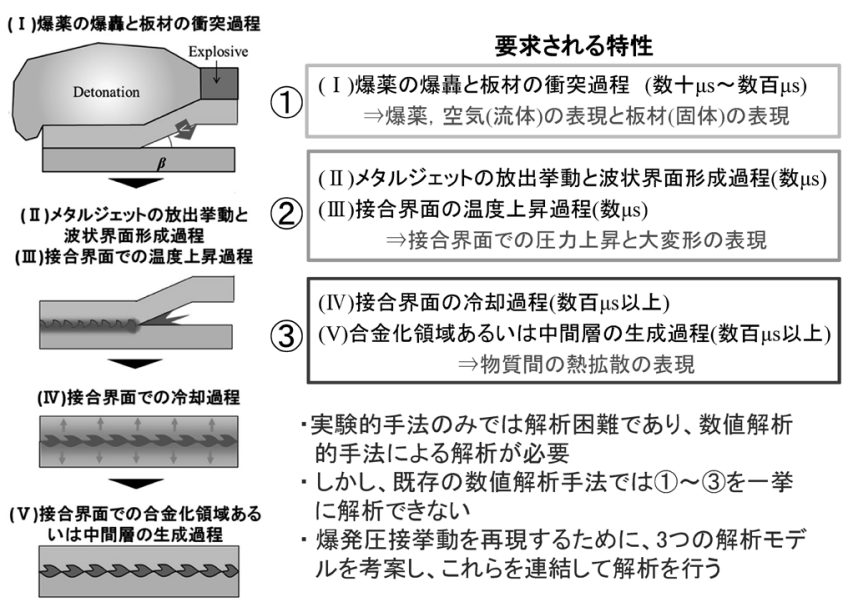

図 1 爆発圧接挙動を構成する過程とこれらを再現する ために必要な解析手法

\begin{tabular}{|c|}
\hline $\begin{array}{l}\frac{\text { Model 1 }}{\text { 爆薬の爆轟と板材の衝突挙動の再現 }} \\
\text { 解析目的 } \\
\text { 衝突速度 } V \text { と衝突角度 } \beta の \text { 算出 } \\
\text { 初期条珄 } \\
\text { 爆薬量、Flyer plateとParent plateの板厚な } \\
\text { らびに間隔、初期傾斜角度 }\end{array}$ \\
\hline $\begin{array}{l}\text { Model 2 } \\
\text { 波状界面の形成過程と接合界面の温度上 } \\
\text { 過程の再現 } \\
\text { 解析目的 } \\
\cdot \quad \text { 接合界面の界面形態(物質分布) } \\
\text { 初接合界面の温度分布 } \\
\text { 衝突速度 } V \text { と衝突角度 } \beta \\
\Rightarrow \text { Model } 1 \text { の結果 }\end{array}$ \\
\hline
\end{tabular}

\begin{tabular}{|c|}
\hline $\begin{array}{l}\text { 接合界面の冷却過程と接合界面での凝 } \\
\text { 解析目的 } \\
\text { • 接合界面の冷却速度の算出 } \\
\text { ・ 合金化領域あるいは中間層の生成 } \\
\quad \text { 過程の再 } \\
\text { 初期条件 } \\
\text { 接合界面の物質分布 } \\
\text { 接合界面の温度分布 } \\
\Rightarrow \text { Model 2の結果 }\end{array}$ \\
\hline $\begin{array}{l}\text { Model 1〜Model 3を組合せて } \\
\text { ( I )〜 ( V)の過程からなる爆発圧接 } \\
\text { 挙動を明らかにする }\end{array}$ \\
\hline
\end{tabular}

図2 考案した3つの解析モデル

定する重要なパラメーターである Flyer plate と Parent plate の衝突速度 $V$ と衝突角度 $\beta$ を求めた。次に, 得られた $V$ と $\beta$ を基に, 衝撃ならびに大变形問題に適したメッシュフリー の解析手法（粒子法）の一種である SPH法を用いた SPH model（Model 2）で（II）メタルジェットの放出挙動，波状 界面形成過程，ならびに（III）接合界面の温度上昇過程を再 現した。この解析により，接合界面の温度上昇範囲，局所融 解領域の生成位置，その形状ならびに組成を明らかにでき た。さらに本解析で得られた接合界面の物質分布，温度分布 に関する知見を基に，熱伝導解析に適した有限体積法を基本 とする lapracianFOAM model（Model 3）を用いて（IV）接合 界面の冷却過程と（V）合金化領域あるいは中間層の生成過 程を再現した。本解析により，接合界面に生成する合金化領 域あるいは中間層の位置，量ならびにその形態を予測するこ とができた9)。

\section{2. $1.3 \mathrm{Cu} / \mathrm{Ni}$ 爆発圧接挙動の数值解析ならびに実験的検} 証

密度差が小さく, 全率固溶する $\mathrm{Cu}$ と $\mathrm{Ni}$ の爆発圧接材を作 製し，併せて $(\mathrm{I}) \sim(\mathrm{V})$ の過程について数值解析による検 討を行った。

$\mathrm{Cu} / \mathrm{Ni}$ 接合界面には正弦波状の波状界面が形成されるが, これはメタルジェットが衝突点前方の $\mathrm{Cu}$ と $\mathrm{Ni}$ の金属表面に 交互に衝突するためであることを数值解析によって明らかに (a) $\mathrm{Cu}$

$\mathrm{Ni}$

$300 \mu \mathrm{m}$

(b) $\mathrm{Cu}$
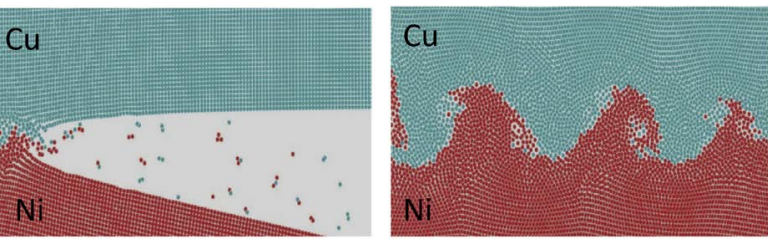

図3（a）爆発圧接した $\mathrm{Cu}$ と $\mathrm{Ni}$ の接合界面に形成した 波状模様（光学顕微鏡写真）と（b）衝撃解析手 法（SPH法）による, $\mathrm{Cu}$ と $\mathrm{Ni}$ の衝突点から発生 するメタルジェットと波状界面形成過程のシミュ レーション結果の比較

した（図3）。数值解析で再現した波状界面の波高と波長は 実験結果と定量的によく一致した。また, メタルジェット の SPH 粒子数比を分析し, $\mathrm{Cu}$ と Ni 比がほぼ $1: 1$ であること, 波の渦部ならびに界面では衝突点近傍で生じる圧縮により急 激な温度上昇が生じるが，界面から数百 $\mu \mathrm{m}$ 離れた位置では ほとんど温度は上昇せず, この大きな温度差によって界面 近傍の冷却速度は $10^{6} \sim 10^{7} \mathrm{~K} / \mathrm{s}$ オーダーとなることを明らか にした。SPH粒子数比により推定した局所融解領域の組成は EPMAにより測定した実際の接合材の合金化領域の組成とよ く一致し, 冷却速度も過去に接合界面の組織観察から推定さ れた冷却速度とよく一致した。

2. $1.4 \mathrm{Cu} / \mathrm{Al}$ 爆発圧接挙動の数值解析ならびに実験的検 証

密度差が大きく, 種々の金属間化合物を生成する $\mathrm{Cu}$ と $\mathrm{Al}$ の組合せで爆発圧接材を作製し, 併せて $(\mathrm{I}) \sim(\mathrm{V})$ の過程 について同様の解析を行った。

この場合には, 衝突点から放出されるメタルジェットは衝 突点前方の $\mathrm{Cu}$ 表面にのみ衝突し, トリガー状の波状界面が 形成された。放出されるメタルジェットの $\mathrm{Cu}$ と $\mathrm{Al}$ の $\mathrm{SPH}$ 粒 子数比はおよそ1:9で, $\mathrm{A} 1$ がその大部分を占めていた。さて, 高速衝突に伴う温度上昇は, 衝突による物体の比内部エネル ギー変化を比熱で除して求められる。比内部エネルギーは, 衝突中の圧力変化に伴う熱力学的仕事によるエネルギーと塑 性変形によるエネルギーの和で表される。高速衝突の際, 衝 突点（接合界面）では数十 GPa まで圧力が上昇し, 大きな温 度上昇がもたらされるが, SPH法を用いると, 任意のSPH粒 子について圧力ゃ変形量の時間変化を求めることができ, こ れにより接合界面や接合界面から離れた母材中での温度上昇 が，それぞれどのような原因で起こるのかについて検討する ことができる。 $\mathrm{Cu} / \mathrm{Ni}$ 爆発圧接材と同様, $\mathrm{Cu} / \mathrm{Al}$ 爆発圧接材 でも波の渦部ならびに界面近傍の温度上昇の主要因は衝突点 近傍で生じる圧縮であると考えられる。一方, 界面から離れ た母材における温度上昇の主な要因は塑性変形であると考え られる。数值解析により予測した接合界面の局所融解領域の 組成は, EPMAにより測定した爆発圧接界面の中間層の組成 とよく一致した。 $\mathrm{Cu} / \mathrm{Ni}$ 爆発圧接材と同様, 接合界面近傍と 母材の間に大きな温度勾配が生じ, 冷却速度は $10^{6} \sim 10^{7} \mathrm{~K} / \mathrm{s}$ オーダーであった。数值解析により, 凝固は局所融解領域の 


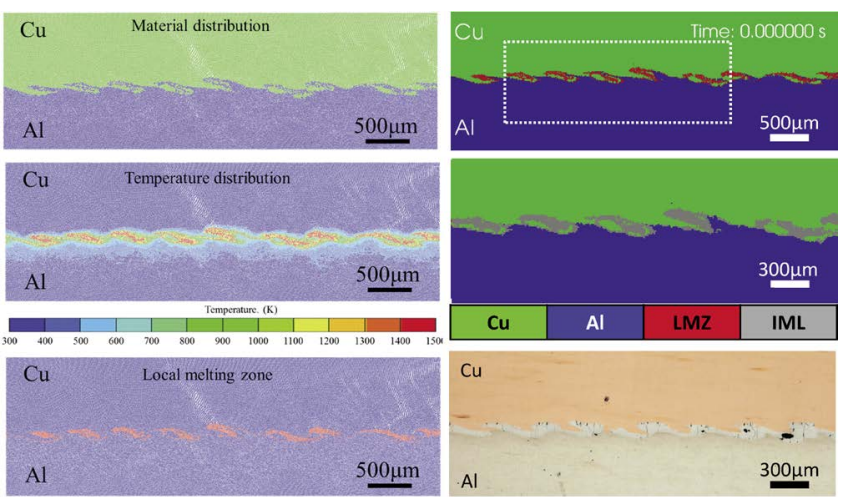

図4 Model 2 を用いて再現した $\mathrm{Cu} / \mathrm{Al}$ の波状界面形態, 温度分布，局部融解領域（左側）ならびにModel 3を用いて再現した中間層生成位置（右側） 右下は爆発圧接によって得られた実際の接合界面

外側から中央部に向かって進行し, 接合界面における中間層 の生成位置は実験結果とよく一致していた ${ }^{10)}{ }^{11 ）}$ (図4)。

2.1.5 $\mathrm{Cu} / \mathrm{Ni}$ ならびに $\mathrm{Cu} / \mathrm{Al}$ の爆発圧接挙動に及ぼす衝突 角度の影響

一定の衝突速度の下，異なる5つの衝突角度で $\mathrm{Cu} / \mathrm{Ni}$ なら びに $\mathrm{Cu} / \mathrm{A} 1$ の爆発圧接材を作製し，併せて爆発圧接挙動に及 ぼす衝突角度の影響について実験と数值解析の両手法を用い て検討を行った。

$\mathrm{Cu} / \mathrm{Ni}, \mathrm{Cu} / \mathrm{Al}$ いずれの場合においても, 衝突角度が大き くなると, メタルジェットの放出量は増加したが, メタル ジェットの温度は低下した。衝突角度によらず接合界面の比 内部エネルギーの総量はほぼ同じであると考えられるため, 比内部エネルギーが増加する範囲が狭いほど接合界面の温度 は高くなると考えられる。よって衝突角度が小さいほど接合 界面近傍での温度上昇が顕著となり，界面に沿って局所融解 領域が生成しやすくなった。一方, 衝突角度が大きい場合に は，接合界面に沿う，より広範囲で温度上昇が起こるため, 接合界面の最高到達温度は低く，渦部のような領域以外で局 所融解領域は生じにくかった。よって, 局所融解領域が急 冷凝固されて生成する $\mathrm{Cu} / \mathrm{Ni}$ 接合界面の合金化領域ならびに $\mathrm{Cu} / \mathrm{Al}$ 接合界面の中間層の生成量は，いずれも衝突角度が大 きいほど少なくなることがわかった（図5）。 $\mathrm{Cu} / \mathrm{Al}$ のような 異種金属接合材においては，衝突角度によって中間層の生成 量を制御し，その生成を抑制すればさらなる接合強度の向上 が図れる可能性があることを明らかにすることができた。

以上示した一連の研究により，異種金属爆発圧接における 接合界面形成メカニズムの解明に成功し，異種金属爆発圧接 材の接合強度を低下させる中間層の生成を抑制する方策を見 出すことができた。

\section{2 実験ならびに数値解析による $\mathrm{Al} / \mathrm{Fe}$ 爆発圧接界面の 組織解析と接合メカニズムの解明}

\subsection{1 背景と目的}

アルミニウム合金と鋼の異種金属接合は，マルチコンポー ネント・マルチマテリアル化に欠かせない技術として注目さ れ, 期待されている。しかし, 両者の融点が大きく異なり, さらに接合界面には脆い金属間化合物が生成するため，通常 の接合法では強固な接合材を得ることが困難であることが知 られている。これに対し本グループでは，電磁圧接によりア
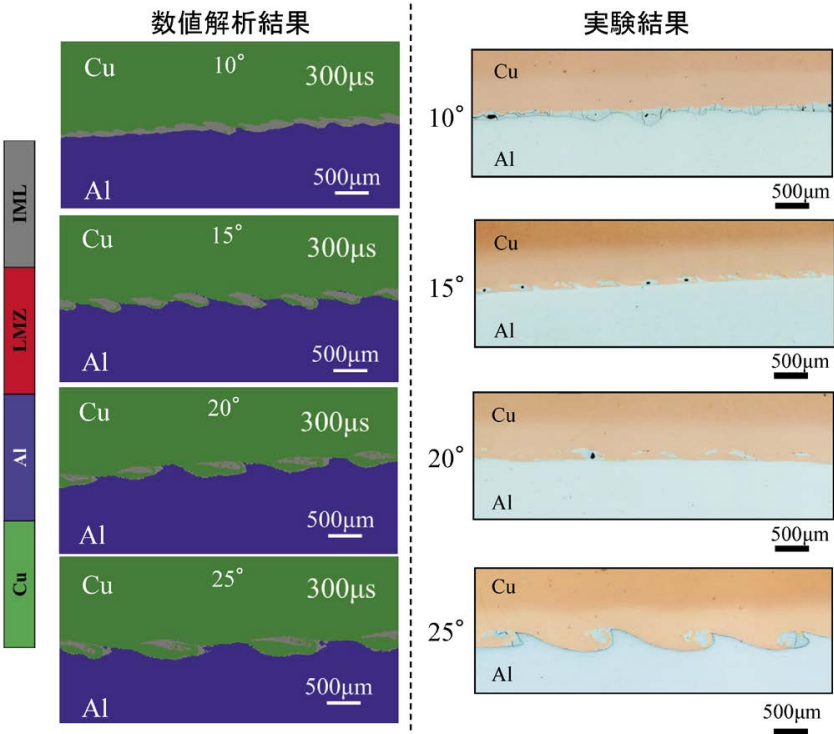

図5 中間層生成に及ぼす衝突角度の影響 数值解析結果 (左側) と実験結果 (右側) の比較

ルミニウム合金と鋼の接合材を作製し，これらが母材破断す るほどの強い接合強度を有することや接合界面には通常の金 属間化合物とはまったく異なる中間層が生成することを明ら かにしている ${ }^{12)}$

そこで本研究では，工業用純 $\mathrm{Al}$ 板 (1100) と低炭素 鋼（SPCC）ならびに 1100 と普通鋼（SS400）の異種金属の 組合せを供試材として選定し，先に示した $\mathrm{Cu} / \mathrm{Ni}$ や $\mathrm{Cu} / \mathrm{Al}$ の 場合と同様, 爆発圧接材の作製とその組織観察等の実験的手 法と数值解析手法を組み合わせることによって, 異種金属爆 発圧接における接合界面形成メカニズムを明らかにし，さら に接合界面に生成する中間層の組成や構造，さらに接合界面 近傍の鋼の組織変化について詳細な検討を行った。

2. $2.2 \mathrm{Al} / \mathrm{SPCC}$ 爆発圧接界面に生成する中間層の組織な らびに構造解析と接合強度

$1100 \mathrm{Al}$ 板と SPCC 鋼板を種々の衝突速度 $V$, 衝突角度 $\beta$ の 条件で爆発圧接した。接合界面にはトリガー状の波状模様と 中間層が観察されたが, それらの大きさや形状は衝突条件に よって異なっていた。またそれぞれの接合条件においてシ ミュレーションにより接合界面を再現したところ, 両者は非 常によく一致した。

$V=750 \mathrm{~m} / \mathrm{s}$, 衝突角度 $\beta=15^{\circ}$ で得られた接合材では, トリ ガー状の波状界面に沿って不連続に中間層が形成していた。 SEM-BEI観察を行ったところ, 接合方向に対し, 各波の前 部と後部に，1対のコントラストの異なる中間層が生成して いた。前部（以下, FSL (Front Side Layer) と表示) は電磁 圧接材の接合界面に見られるような溶融の痕跡のない中間層 であったのに対し，後部（以下，TSL（Tail Side Layer）と表 示）は，デンドライト凝固組織を呈していた。TEM-EDXを 用いて組織観察ならびに組成分析を実施したところ, FSLは $\mathrm{Fe}$ を $10 \%$ 程度固溶した $\mathrm{Al}$ で構成されるのに対し，TSLには 金属間化合物の $\mathrm{Al}_{3} \mathrm{Fe}$ や $\mathrm{Al}_{5} \mathrm{Fe}_{2}$ の存在が確認され, $\mathrm{Al}$ と $\mathrm{Fe}$ の 質量比は $1: 1$ であった。

SPH 法を用いた数值解析によって再現した接合界面におけ るSPH粒子分布に注目し，FSL, TSLに対応する位置での $\mathrm{Al}$ と $\mathrm{Fe} の$ 粒子数の比を求め, これを質量比に換算したところ, 
(a)

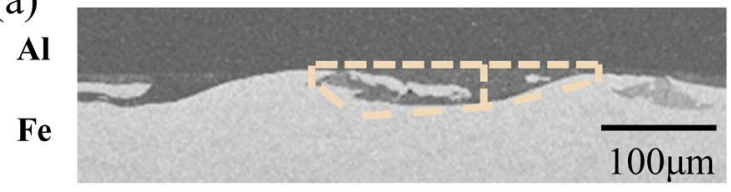

(b)

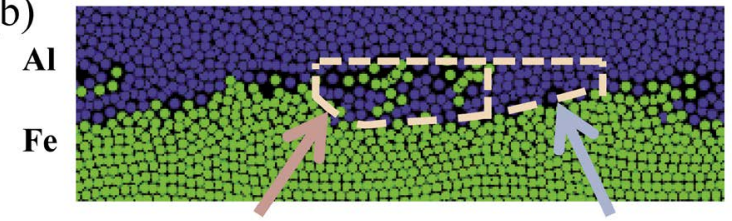

"TSL region"

(c)

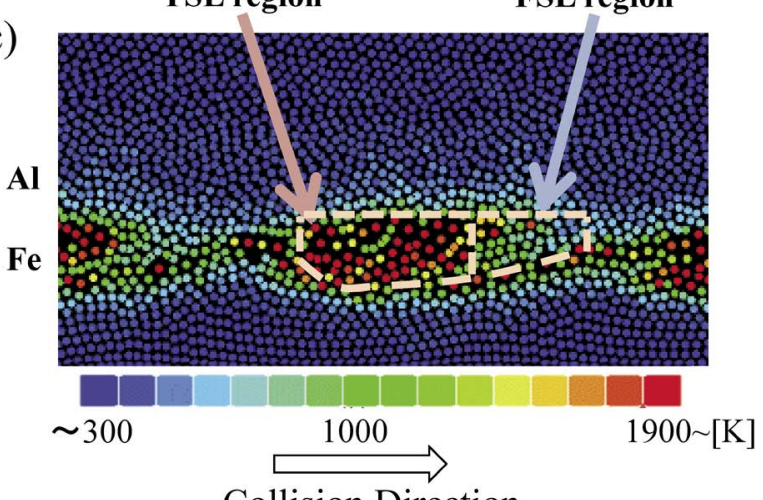

Collision Direction

図6 $\mathrm{Al} / \mathrm{Fe}$ 爆発圧接材の界面組織と粒子法による衝突 シミュレーション（板厚 $2 \mathrm{~mm}, \quad V=700 \mathrm{~m} / \mathrm{s}, \quad \beta=$ $\left.15^{\circ}\right) 。(a) \mathrm{SEM}-\mathrm{BEI}$ 組織, (b) $\mathrm{Al} / \mathrm{Fe}$ の物質分布, (c) 温度分布

実験で得られた中間層の組成とよく一致した。また，SPH法 で接合界面の温度について解析したところ，FSLの位置での 最高温度は $\mathrm{Al}$ の融点以下であるが, TSLの位置では $\mathrm{Fe}$ の融 点以上に達することがわかった。この結果は, 実際の爆発圧 接界面に扔ける中間層の様相とよく対応して扔り,TSLは局 所融解と凝固によって生成された中間層であることを示唆す るものである（図6）。

このように衝突速度 $V$, 衝突角度 $\beta$ にっって接合界面の形 態や温度分布は変化し, さらに各波の中でもその温度や組成 が場所によって異なることがわかった。本研究により, 数值 解析を用いて接合界面での組成分布と温度分布を予測するこ とにより，実際の爆発圧接界面での中間層の生成を制御し て，さらに接合強度を向上できる可能性があることが明らか となった ${ }^{13)}$ 。

2. $2.3 \mathrm{Al} / \mathrm{SS} 400$ 爆発圧接界面に生成する中間層ならびに 接合界面近傍のSS400の組織変化

供試材に相変態をする鋼を用いることにより，接合前後の 組織の違いから爆発圧接時の界面近傍の局所的な熱履歴（温 度変化）の違いを明らかにすることができるのではないかと 考え，一連の研究を実施した。

本爆発圧接材に扔いても接合界面にはFSLと TSL の 2 種類 の中間層が観察された。実際に得られた中間層をEPMAによ り組成分析し, これをSPH法による衝突点近傍に打ける波 状界面形成過程のシミュレーション結果と対応させて検討を 行った。その結果, FSLは, 主としてFlyer plateである $\mathrm{Al} の$ 塑性変形によって形成され，一方，TSLは渦を巻く波の先端 部にメタルジェットが巻き込まれて形成されることがわかっ た。
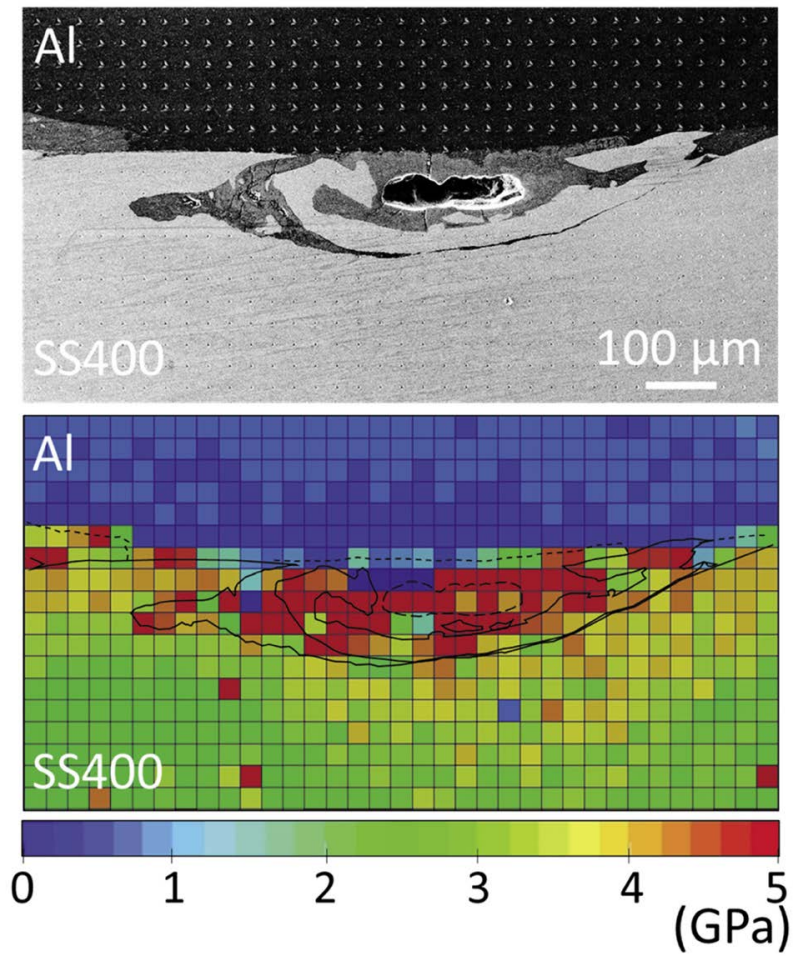

図7 Al/SS400接合材の界面組織とナノインデン テーションによる硬さマッピング（板厚 $6 \mathrm{~mm}$, $\left.V=650 \mathrm{~m} / \mathrm{s}, \quad \beta=15^{\circ}\right) 。 30 \mu \mathrm{m}$ 間隔で硬さ測定を実施

SS400は，フェライトとパーライトの2相組織を呈するが, 接合後, 波の先端部近傍はマルテンサイト組織に, 接合界 面近傍は細長く引き伸ばされた筋状の 2 相組織に変化してい た。ナノインデンテーションを用いてSS400内の微小硬さを 測定したところ, 接合界面に近い位置ほど硬化して㧍り, 渦 部で最も硬くなっていた。 $\mathrm{Al}$ も接合界面に近いほど硬化し ていたが，界面の極近傍ではいくぶん軟化していた（図7）。

このような組織と硬さ変化は, 最高到達温度とその後の泠 却過程に関する数值解析結果とよい対応を示していた。すな わち, 波の先端部近傍ではSS400がオーステナイト化する温 度まで急速加熱され，その後急冷されることでマルテンサイ 卜変態が起こり著しい硬化が生じたこと, 接合界面極近傍の $\mathrm{Al}$ は著しい塑性変形のため加工硬化するものの, 温度上昇 による軟化が生じたと考えられる。

接合界面形態と中間層の生成に及ぼす衝突条件の影響につ いて, 実験と数值解析の両手法を用いて調べたところ, 衝突 速度が増加するほど波状界面の波高が高くなること, 中間層 生成位置での最高到達温度が上昇し, 中間層に含まれる $\mathrm{Fe}$ 成分が増加することも明らかとなった。

\section{3 本解析手法の電磁圧接への展開}

電磁圧接は放電回路を用い, コンデンサに蓄積した電荷を 放電してコイルに瞬間的に電流を流して電磁力を発生させ, これを駆動力として金属板同士を衝撃圧接する手法である。 長尺で板厚の大きな金属板を接合するための爆発圧接に比 へ,, 電磁圧接は, 薄板同士の接合, 薄板と厚肉材の接合, 管 と管や管と中実棒との接合に利用できる。

しかし, 電磁圧接では放電電流の変化に伴う電磁場の変化 によって金属同士の衝突速度 $V$ や衝突角度 $\beta$ が時々刻々と変 化し, 爆発圧接の場合のように一定の衝突速度, 衝突角度で 


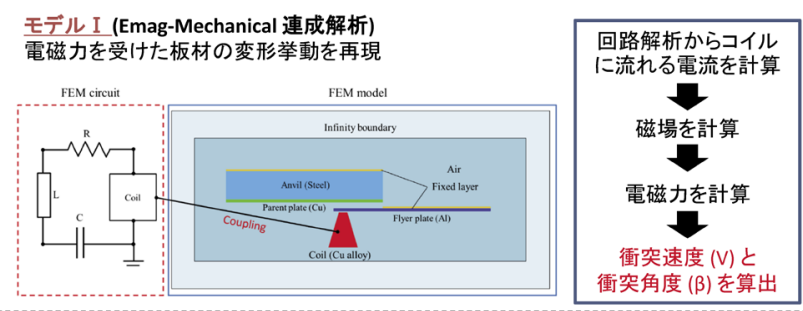

モデル I (Autodyn) $\Rightarrow$ 波状界面の再現とそれに伴う界面温度の変化の再現

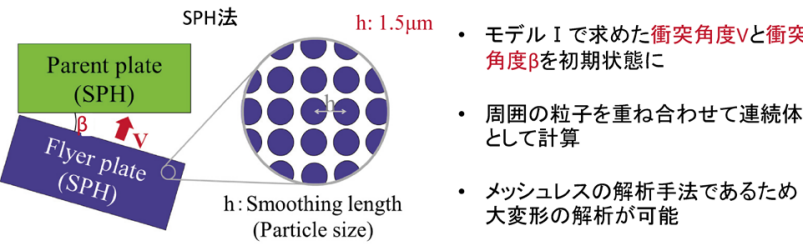

(a)

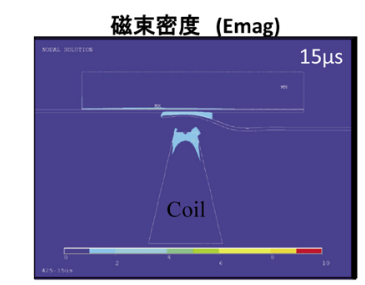

電流波形(接合条件A)
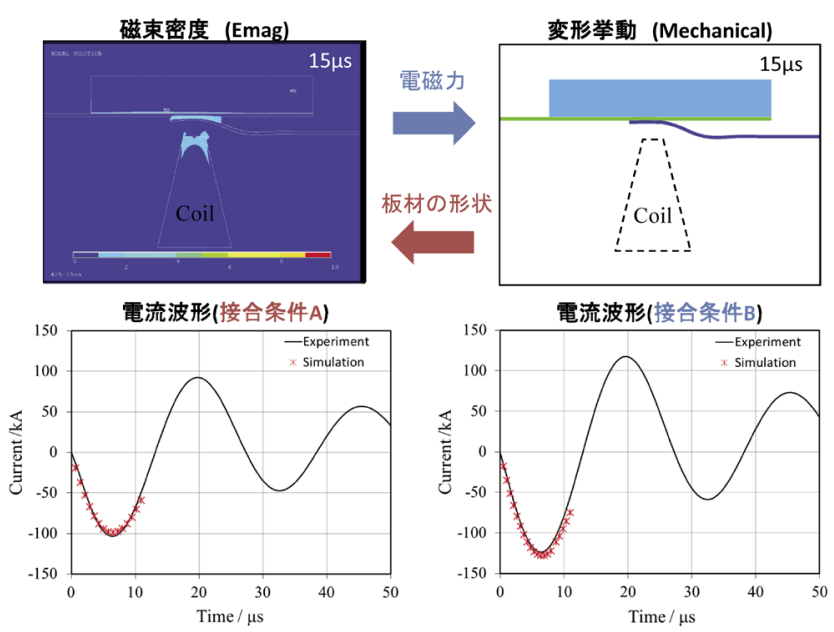

(b)

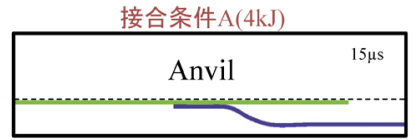

衝突角度: $7.1^{\circ}$

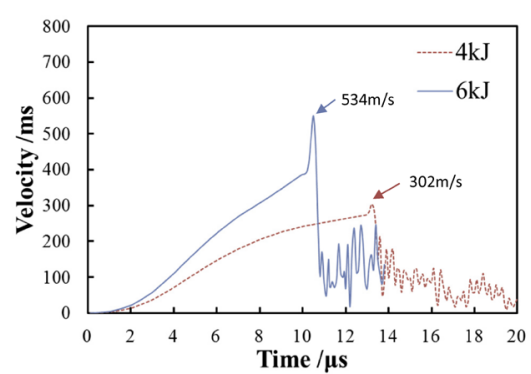

(c)

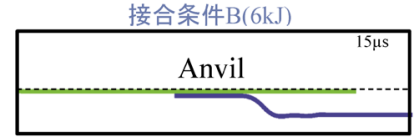

衝突角度: $16.2^{\circ}$

電磁力衝撃圧接の数值解析手法。（a）解析に用い た Model I と Model II, （b） Emag-Mechanicalを用 いた磁場－構造連成解析と電流波形, （c）電磁力 衝撃圧接における衝突速度 $V$ と衝突角度 $\beta$ の再現

接合が進行しないため, 実験的にも数值解析的にも取り扱い が難しい。また, 電磁圧接は爆発圧接に比べて低エネルギー であることが利点の 1 つであるが，そのため接合界面に形成 する波の大きさが小さく, 数值解析により複雑な波の形状を 再現するためには, メッシュやそれに代わるSPH粒子の寸 法をかなり小さくする必要がある。よって, モデル作製や計

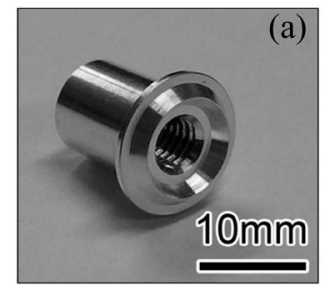

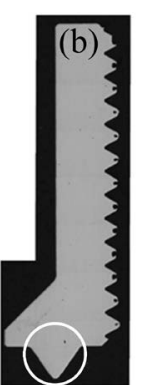

Projection

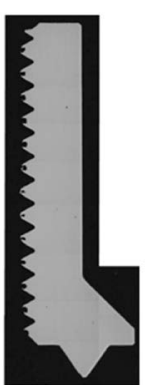

$1 \overline{\mathrm{mm}}$
図9 スタッド外観図（a）ならびに断面図（b）

算に膨大な時間を要するといった問題があり，それらを克服 するための工夫が必要である。

そこで本グループでは，Emag-Mechanicalを用いた磁場一 構造連成解析によって電磁力を受けた金属板や管の変形挙 動とそれらの相手材である板や棒への衝突挙動を再現して いる（図8 (a)～(c)）。そして電磁力圧接における衝突速度 $V$ と衝突角度 $\beta$ を求め, 爆発圧接の場合と同様の手法でメタル ジェットの放出挙動, 波状界面形成過程, 接合界面の温度上 昇過程と冷却過程を再現し, 実際の $\mathrm{Al} / \mathrm{Fe}, \mathrm{Cu} / \mathrm{Al}, \mathrm{Cu} / \mathrm{Ni}$ 等の 電磁圧接材の接合界面組織と比較している。

\section{4 固相スタッド接合法による種々の異材接合材の接合 強度と界面組織}

\section{4.1 背景}

金属のねじやピンなどの突起物（スタッド）を金属の相手 材に接合する手法として, 種々のスタッド接合法が開発され てきた。これら従来の接合法は, いずれもアークや抵抗発熱 を利用して被接合材を十分に加熱・溶融させ, スタッドを相 手材に押し付けることで接合を行う, いわゆる溶融溶接法で あった。しかし，この方法では被接合材に与える熱影響が大 きく, 相手材の変形や溶接痕の発生を引き起こす場合があ り, 特に薄板や表面処理板へのスタッド接合においては大き な問題となっていた。それらの問題点を解決するために, 被 接合材を溶融させることなく接合可能な「固相スタッド接合 法」が開発された。本手法で用いるスタッドの外観図と断面 図を図9に示す。スタッド底部には断面が逆三角形状の環状 プロジェクションが設けてある。接合装置には銅製の二重円 筒管型電極を用いる。スタッドを内部電極に取り付け, 空気 圧によって板表面に押し付ける。コンデンサからの放電大電 流が内部電極からプロジェクションと板表面の接触部から外 部電極へと流れる。ジュール熱により接触部の局所的な温度 上昇が生じる。数ミリ秒という非常に短時間の放電大電流と 加圧により，環状プロジェクションを軟化・塑性変形させ, 接合材表面の酸化被膜が破壊されることで新生面の接触が生 じ，接合材の金属的接合が達成される。スタッド形状・電極 形状・電流経路を工夫したことで接合材の温度上昇を抑え， 板の変形や溶接痕の発生を防止しつつ強固な接合が可能と なった。これまでに, 固相スタッド接合法を用いて, Al合 金スタッド（A2024）を A1合金板（A5052ならびにA6N01） に接合し, 接合界面組織や接合強度などについて種々の報告

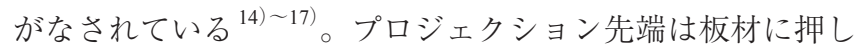
达まれ, その両側でプロジェクションが塑性変形して接合が なされた。接合材の破断強度が板材の最大引張強度に匹敵す 
るほど強固に接合された。また，鋼スタッド（SS400）と鋼 板（SPCC）あるいは $\mathrm{Al}$ 合金スタッド (A2024）と Mg 合金 板（AZ80）の固相スタッド接合も行っている ${ }^{18), 19) 。 い す ゙ れ ~}$ も板の変形や溶接痕を生じることなく接合可能であることを 見出している。このように固相スタッド接合法は同種金属材 料だけではなく，異種金属材料の接合にも適用可能である。

近年，各種産業製品に要求される材料特性は多岐にわた り, 単独材料での達成が困難であることも多い。種々の材料 を適材適所で組み合わせ，互いの欠点を克服した高機能材料 が求められている。その 1 つとして，Al合金と鋼の接合の有 用性は古くから認められているが, 従来の溶融溶接法では接 合界面に脆弱な金属間化合物が厚く形成してしまい，接合強 度が低下する。強固な接合材を得るためには，金属間化合物 の形成を抑制する必要があり，そのためには接合時の入熱を 低減する必要がある。また，樹脂板を金属薄板で挟んだ金属 樹脂積層板は，軽量構造材として国内のみならず海外におい ても様々な場所で多用されている。この積層板を他の部材と 締結するために，ボルトなどのスタッドを積層板に接合する 必要がある。本積層板は内部に樹脂が存在するため一般的な 溶融溶接法を用いることができず，積層板に芯材樹脂まで穴 あけ加工後，アンカー付きのスタッドを挿入する機械的な接 合がなされていたが，工数がかかるうえに熟練度が要求され る作業であった。固相スタッド接合法では, 接合時の熱影響 部は板のごく表面のみに限られるため，芯材樹脂を溶かすこ となく金属樹脂積層板への簡便な接合を実現する方法として 本接合法は適用可能だと考えられる。

そこで，固相スタッド接合法により，鋼スタッド（SS400） と $\mathrm{Al}$ 合金板（A5052）ならびに $\mathrm{Al}$ 合金スタッド (A2024）と 金属樹脂積層板を接合し，接合条件が接合界面組織や接合強 度に及ぼす影響を調査した。

\subsection{SS400スタッドとA5052板の接合 20 )}

供試材には鋼スタッド（SS400）と Al合金板（A5052-H34, 板厚 $1.5 \mathrm{~mm}$ ）を用いた。接合には曙機械(株所有の接合機を用 いた。接合条件として, 加圧力とコンデンサ容量は一定とし, コンデンサへの充電電压は各接合材で良好な接合ができる条 件を選定した。450V接合材のプロジェクション近傍の断面 写真を図10に示す。接合界面の全体にわたって大きな隙間 は観察されなかった。プロジェクション内側ならびに外側に

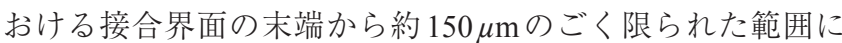
は, 厚さ $1 \mu \mathrm{m}$ 程度の中間層が観察された。この中間層を $\mathrm{FE}-$ SEMの反射電子像により拡大観察すると，2色のコントラス 卜を呈することがわかり, $\mathrm{Al}$ 合金板側の相は鋸歯状の組織 を呈していた。これらの組織は過去の研究報告から, $\mathrm{Al}_{5} \mathrm{Fe}_{2}$ 相（鋼スタッド側）ならびに $\mathrm{Al}_{3} \mathrm{Fe}$ 相（ $\mathrm{Al}$ 合金板側）である と考えられる ${ }^{21)}$ 。接合界面の大部分では，厚さ $100 \mathrm{~nm}$ 程度 の中間層がアイランド状にわずかに観察されるのみであり, 接合強度に悪影響を及ぼすような厚い中間層は観察されな かった。引張試験後の破断面観察の結果, プロジェクション 先端部に対応する箇所ではフラットな破断面を呈しており, 未接合部あるいはとても弱い接合がなされた場所であった。 一方, 先端部より両側では延性破壊を示すディンプル破面が 観察された。この箇所では接合界面での剥離や破壊が生じる ことなく, $\mathrm{Al}$ 合金板側で母材破断するほど強固な接合がな された。充電電圧と破断荷重の関係を図 11 に示す。破断荷

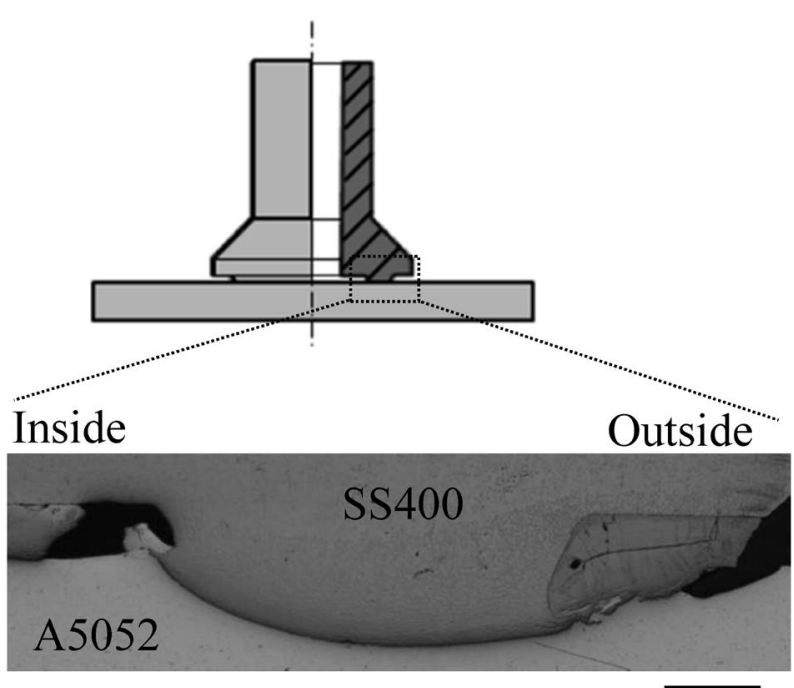

$\overline{300 \mu \mathrm{m}}$

図 $10450 \mathrm{~V}$ 接合材（SS400/A5052）の断面写真

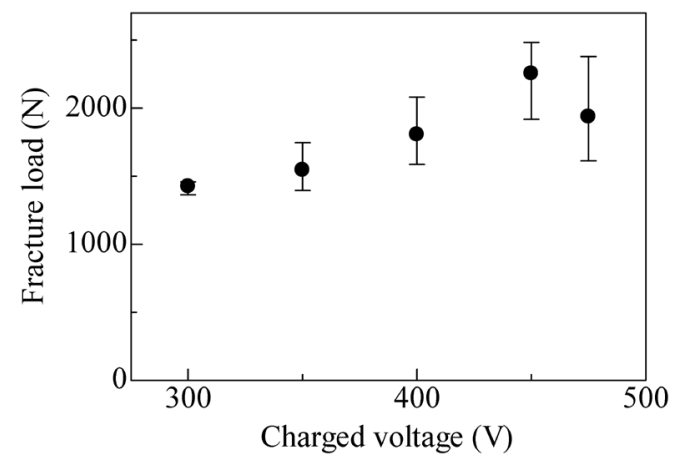

図11 充電電圧と破断荷重の関係（SS400/A5052）

重は充電電圧の上昇に伴い $450 \mathrm{~V}$ ま゙゙増加したが, $475 \mathrm{Vで}$ はわずかに減少した。破断面でディンプル組織が観察された 領域の面積と充電電圧の関係を調べたところ, ディンプル組 織の面積は充電電圧の上昇に伴い $450 \mathrm{~V}$ ま゙゙増加し, $475 \mathrm{~V}$ ではわずかに減少するという図11 と同様の傾向を示した。 母材破断するほど強固に接合した面積の増加が, 接合強度の 増加に寄与したと考えられる。475V接合材ではプロジェク ション外側の溶融による接合面積の減少に加え, 内側接合界 面においても厚さ $1 \mu \mathrm{m}$ 程度の中間層形成領域が増加してい たことから，過剰な入熱によって接合強度が低下したと考え られる。

\subsubsection{A2024スタッドと金属樹脂積層板の接合 ${ }^{22)}$}

供試材には $\mathrm{Al}$ 合金スタッド (A2024) と金属樹脂積層板 (皮 材 : A $3105-\mathrm{H} 14$, 板厚 $0.5 \mathrm{~mm}$, 芯材：ポリオレフィン系樹脂, 板厚 $3 \mathrm{~mm}$ ）を用いた。図9に示したプロジェクション断面を 有するスタッドで接合を試みたところ, プロジェクション先 端が皮材を突き破って芯材内部にまで貫入し，接合材を得る ことができなかった。金属樹脂積層板の皮材が非常に薄く, また芯材樹脂が軟らかいためたと考えられる。そこで, こ のような問題を解決するために, プロジェクション先端がよ り平坦で，かつ内側に傾けたスタッドを作製して接合に供し た。得られた接合材の断面組織写真を図 12 に示す。プロジェ クション先端部ならびに板材の変形が観察され, 板材の一部 


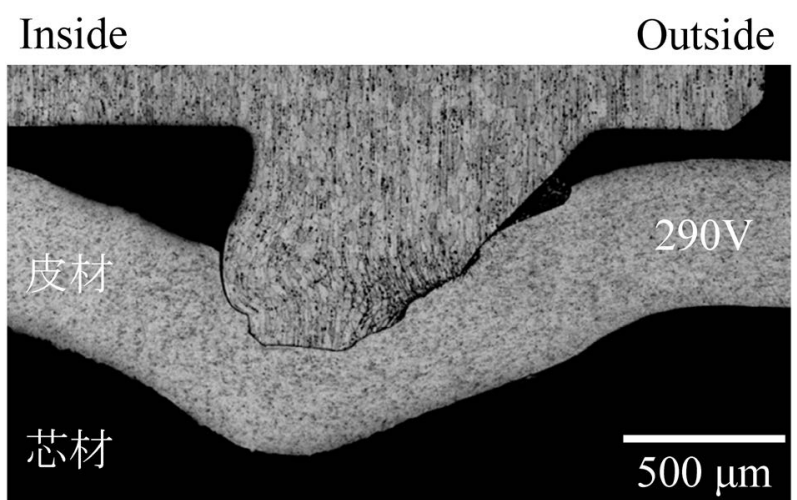

図 $12290 \mathrm{~V}$ 接合材（A2024/金属樹脂積層板）の断面写 真

は薄くなっていた。結晶粒組織から，特にプロジェクション 先端の外側で変形が大きかったことが伺える。接合は主にそ の部分でなされており, 接合面積は充電電圧の上昇に伴い増 加した。充電電圧と破断荷重の関係を図13に示す。290Vま では破断荷重が増加したが，300Vでは減少した。290Vなら びに $300 \mathrm{~V}$ 接合材は共に板材での母材破断であったが，局所 的な皮材厚さの減少が $300 \mathrm{~V}$ 接合材の方が大きかったため, これが破断荷重減少の要因であると考えられる。接合材の破 断は皮材と芯材の界面で生じていた。このことは金属樹脂積 層板の構造強度（接着強度）よりもスタッドと積層板の接合 強度の方が大きかったことを意味しており，金属樹脂積層板 へのスタッド接合に本手法が十分に適用可能であったと言え る。

\section{3. 電磁圧接による熱処理型アルミニウム合金の} 同種・異種金属接合板作製と接合メカニズム (千葉大学グループ)

\section{1 電磁圧接}

電磁圧接は固相接合法の一種として知られており, 電磁力 を用いた電磁成形法は導電率の高い材料ほど大きな渦電流 が誘起されるので，金属材料の成形に適している。1960年 に金属円管を成形または接合する方法として特許が公表さ れ ${ }^{23)}$ ，円管について機械式締結または縮管による接合法と して報告されている ${ }^{24)}$ 。その後, 従来の成形用コイルより 構造が簡単で機械的強度の高い平板ワンターンコイルを用い た電磁シーム接合法が相沢により提案され，純アルミニウム 板の重ね接合が可能であると報告された ${ }^{25)}$ 。電磁圧接は可 動板に急激に磁束を加え, 高速度で固定板に衝突させて接合 する電磁力衝撃による接合であり，爆発圧着と類似した高速 固相接合法である。本グループでは，電磁圧接により，一般 的に溶融溶接が困難な熱処理型アルミニウム合金板の高速 固相接合を行った。2000系および7000系アルミニウム合金 について，各々の板の同種接合を行い，また6000系アルミ ニウム合金においては実用を踏まえ，冷間圧延鋼鈑（SPCC） または高張力鋼板との異種接合を行い, 高い接合強度を有す る接合板を作製し, 詳細な組織観察を行って, その接合メカ ニズムを考察した。

図 14(a) に電磁圧接装置の断面の模式図を示す。図に示 すようにコイルの上に2枚の金属板に間隙を設けて設置す る。このときの下側の金属板を可動板，上側の金属板を固定

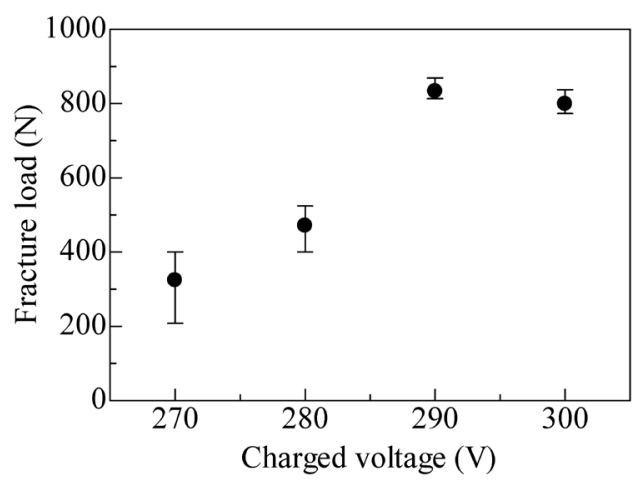

図 13 充電電圧と破断荷重の関係（A2024/金属樹脂積 層板)

(a)

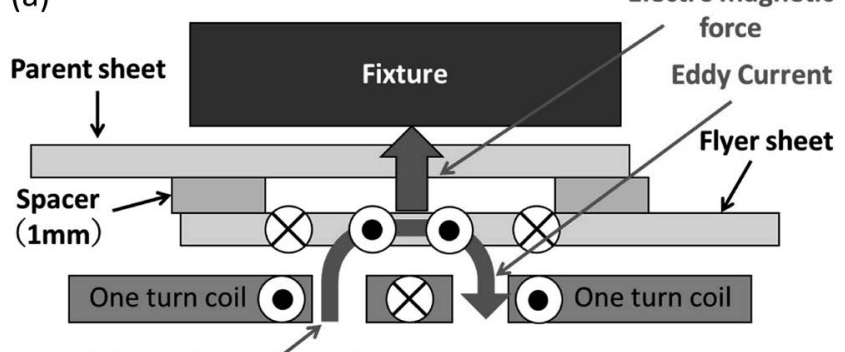

High density magnetic flux

(b)

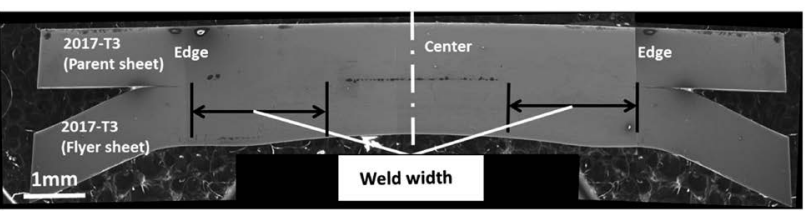

図 14 （a）電磁圧接装置の断面の模式図，（b）2017-T3 板同士の接合板の断面 SEM像

板と呼ぶ。この状態でコンデンサ電源に電気エネルギーを充 電する。放電ギャップスイッチを閉じるとコンデンサ電源か ら放電され，コイルにパルス大電流が流れる。コンデンサ電 源に充電した電気エネルギーは接合条件の1つであり, 以後 これを放電エネルギー $W$ と表記する。コイルに瞬間的にパ ルス大電流が流れると, 高密度磁束がコイル中央部の周辺に 発生し，磁束が可動板に交差すると，磁束の侵入を妨げるよ うに可動板内に渦電流が誘導される。高密度磁束と誘導され た渦電流が交差して電磁力が発生する。可動板は上向きの電 磁力を受けて変形して高速度で固定板に衝突して接合され $3^{12), 26)}$

図 14(b) に2017-T3 板同士の接合板の断面 SEM 像を示す。 上側が固定板で，下側が可動板である。電磁圧接では，中心 部から端部側に向けて接合過程が進行するにつれて衝突点の 移動速度と衝突角度が波状界面接合の条件を満たすようにな る部分で接合が行われる。したがって，一点鎖線で示す中心 線に対して対称に，ほぼコイル幅に相当する左右の 2 か所で 線状に接合が行われる。以後, この2か所を接合部，また その幅の合計を接合幅と呼ぶ。

\section{2 衝突時間の測定と接合板の作製}

2017-T3 板同士または2024-T3 板同士の接合板を $W=2.0$ $3.5 \mathrm{~kJ}$ で作製した後に室温にて引張せん断試験を行った。い 
ずれの接合板も放電エネルギーが増加するにつれて破断荷 重が増加し，Wが 3.0 および $3.5 \mathrm{~kJ}$ では両接合板ともに母材 の $95 \%$ 以上の荷重にて母材破断となった。以上の結果から, 2017-T3 板および2024-T3板同士の電磁圧接による接合が可 能であり，Wが $3.0 \mathrm{~kJ}$ 以上で母材破断となる強固な接合が可 能であった ${ }^{27)}$ 。しかしながら，2024-T3/2024-T6接合板の作 製においては，さらに放電エネルギーを増加して， $3.5 \mathrm{~kJ} に$ て接合を行った結果，接合は可能であったものの，母材破断 する強固な接合はできなかった。2024-T6板の $0.2 \%$ 耐力や硬 さ值は2024-T3板よりも高く，また，伸びは半分程度であり， 電磁圧接において，機械的強度が高く，延性に乏しい材料は 接合しにくいことが示唆された。強固な接合を達成するため には，さらに放電エネルギーを増加させ，衝突速度を速くす ることで，衝突圧力を増加させて接合する方法がある。しか し, 放電エネルギーの増加はコイルへの負担増加を意味し, コイルの変形はコイル寿命に悪影響を及ぼす。

そこで, 可動板と固定板の間隙長を変化させて電磁圧接を 行い可動板が固定板に衝突する時間を測定し，その衝突速度 を調べた。図 $15 に ，$ 放電エネルギーを $2.0 \mathrm{~kJ}$ とて，2017$\mathrm{T} 3$ 板を可動板とした時の衝突時間 $t$ と衝突速度 $V$ および間隙 長 $d$ との関係を示す。衝突時間は間隙長の増加に伴い増加し, また，衝突速度は $d=2.0 \mathrm{~mm}$ で最大の $380 \mathrm{~m} / \mathrm{s}$ に達し，その後 は低下することがわかる。衝突圧力 $P$ は $d$ が $2 \mathrm{~mm}$ において $2.65 \mathrm{GPa}$ と見積もることができた ${ }^{1)}{ }^{28)}$ 。間隙長が広がるにつ れて衝突速度が上昇するのは，可動板が電磁力により固定板 側へ変形する祭に，十分に加速するまで時間がかかるためで ある。また，衝突速度が最大値に達した後に低下するのは， 間隙長の増加に従い，電磁力が可動板に及ぼす影響が小さく なるとともに, 可動板の変形量が大きくなり, 加工硬化に よる変形抵抗が高くなるためであると考えられる。つまり, 間隙長の設定により衝突速度を調整することが可能である。 以上のことを踏まえ，間隙長を変化させて 2024-T3/2024-T6 接合板 $(W=3.5 \mathrm{~kJ}, d=1.3 \mathrm{~mm})$ および2024-T3/7075-T6 接合 板 $(W=3.0 \mathrm{~kJ}, d=1.3 \mathrm{~mm})$ を作製し，室温にて引張せん断試 験を行った。いずれの接合板も 2024-T3板側で母材破断とな る強固な接合が達成できた。このことは, 間隙長を適切な值 に設定することで，良好な接合状態を得るために必要な放電 エネルギーを低く抑えることも可能であることも意味してい る。

同様に，6061-T6板と590MPa級の高張力鋼板 (JSC590Y) について接合（ $W=3.0 \mathrm{~kJ}, d=1.0$ または $1.3 \mathrm{~mm} ）$ を行った。図 16（a）に接合板作製時の間隙長の違いによる破断荷重の変化 を示す。実線は6061-T6板の破断荷重を示す。 $d$ が1.0 mmで は母材の約 70\%の荷重で接合部剥離したが, 図 16(b) の引 張せん断試験後の試験片の外観写真からもわかるように, $d$ が1.4 mmでは6061-T6板側で破断しており，強固な接合がで きたと考えられる。1050,5052または6061-T6板と SPCC板の 接合では $d$ が $1.0 \mathrm{~mm}$ においていずれも $W$ が $2.8 \mathrm{~kJ}$ 以下で良好 な接合が達成できていることから，Al合金板同士の接合の 結果からも鑑みると，電磁圧接では，機械的強度が高く，か つ延性に乏しい板の接合において，可動板の衝突速度を速く する必要があり，純金属板同士の接合と比較して接合条件が より狭くなると言える。

以上の結果から, 放電エネルギーの増加や間隙長を広げる

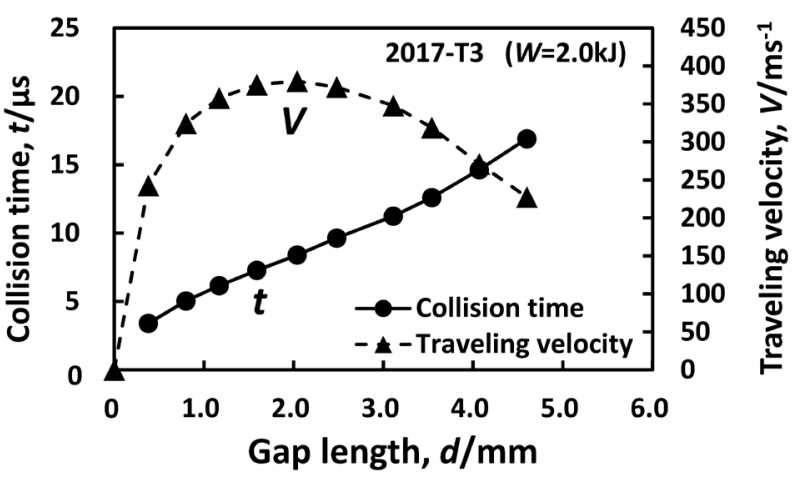

図 15 2017-T3板の間隙長の変化による衝突時間と衝突 速度の関係 $(W=2.0 \mathrm{~kJ})$

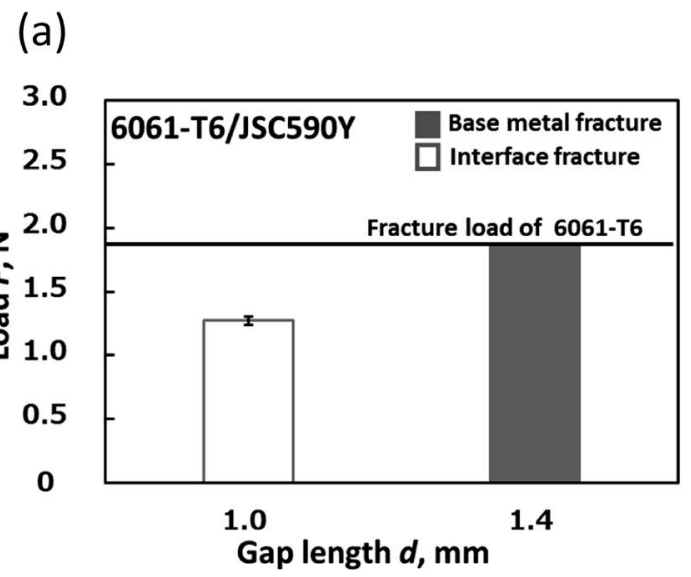

(b)

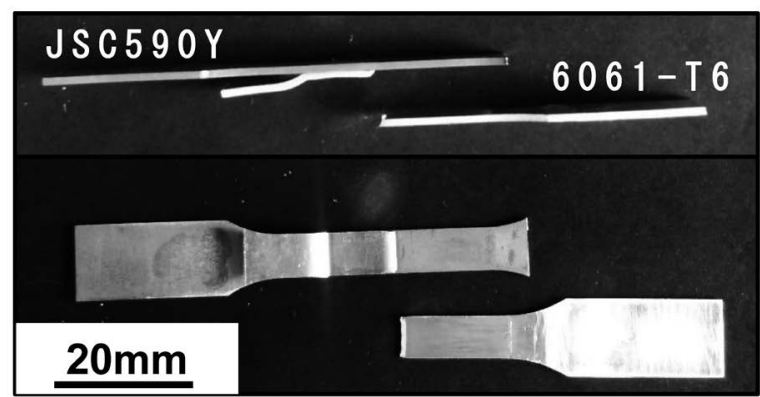

図16（a）接合板作製時の間隙長の違いによる破断 荷重の変化。実線は6061-T6板の破断荷重を示 す。（b）引張せん断試験片の試験後の外観写真

ことで，比較的速い衝突速度で電磁圧接を行うことは，接合 強度を向上させ，また，電磁圧接による接合が困難な材料を 接合する上で効果的であることが明らかとなった。

\section{3 接合界面の組織観察}

図14(b) に示したように，各接合板の接合幅を調べた結果， 放電エネルギーや間隙長の増加により接合幅が広くなること がわかった。また，強固な接合ができた接合界面からは衝 撃波の伝播に起因する波状模様が観察された。図 $17(\mathrm{a})$ に $W$ を $3.0 \mathrm{~kJ}$ として接合した2024-T3 接合板の接合界面の TEM 像を示す ${ }^{27)}$ 。図の上側が固定板, 下側が可動板である。図 の TEM像において, 矢印で示した部分に固定板と可動板の 界面に隙間が存在し，この領域が未接合界面であることがわ かる。また，可動板側に観察される $\mathrm{MgCuAl}_{2}$ 相には矢印で 

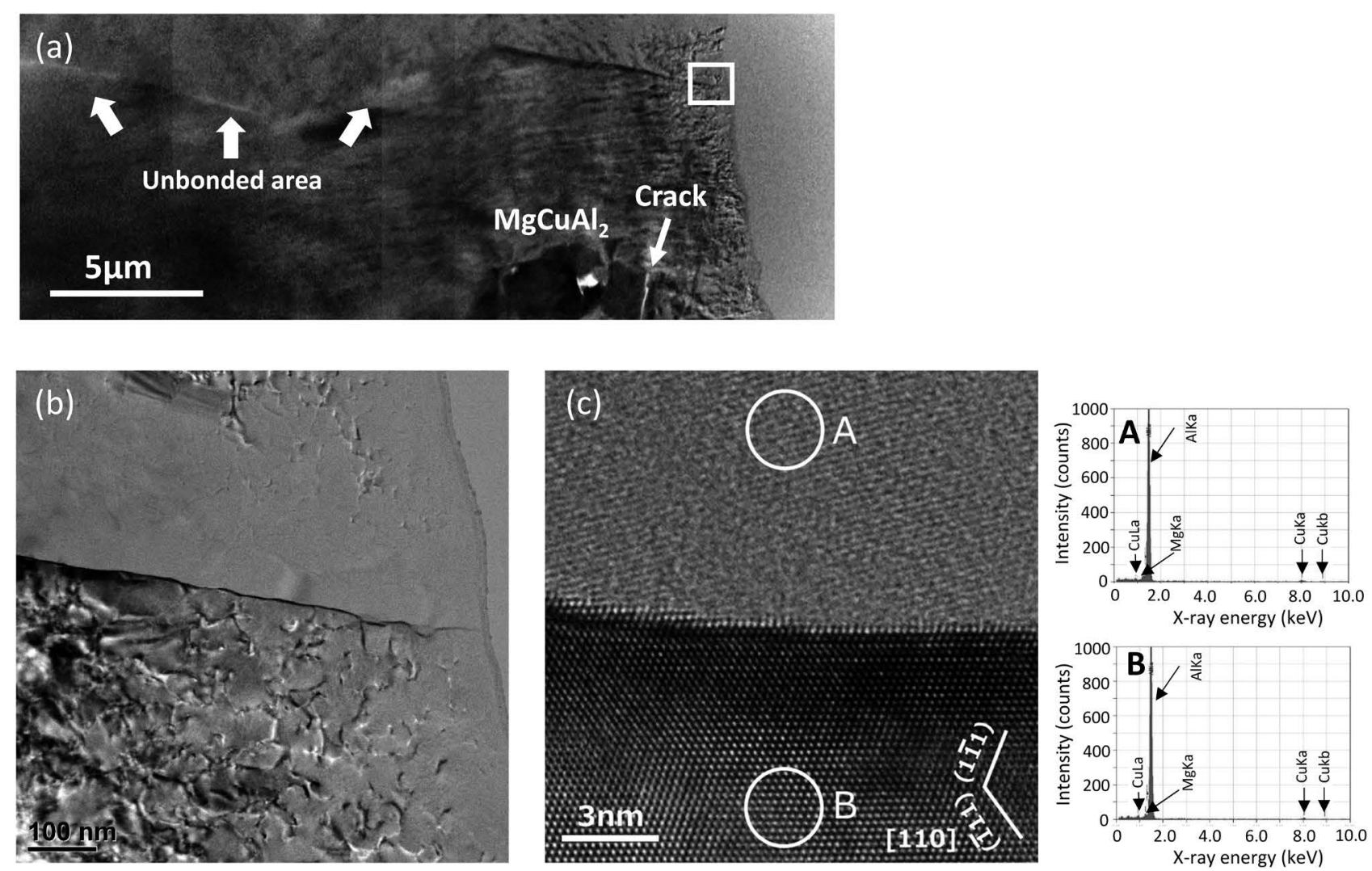

図 17 (a) 2024-T3 接合板の接合界面のTEM像（W=3.0kJ），(b）（a）のTEM像中に白枠で示した部分の拡大図，（c）接 合界面の高分解能 TEM像，図中の領域 A と Bについて調べたEDS 分析結果を併せて示す

示すように衝撃に起因する割れが生じており，この界面が 接合界面であると考えられる。図 17 (a) のTEM像に白枠で 示した部分の拡大図を図17(b) に示す。図の接合界面から は，微細な酸化物は観察されず，界面も結晶粒に沿って直線 的であり溶解した跡はうかがえないことから固相状態で接合 されたと考えられる。また, 可動板の界面下の組織からは, 転位によるコントラストも観察され，接合界面近傍ではひ ずみが蓄積して加工硬化している。図17(c) にこの接合界 面の高分解能 TEM 像を示す。下部の可動板の Al 相について [110］入射で観察した。また, 眓には領域 A と Bについて 約 $3 \mathrm{~nm}$ 程度までビームを絞って EDS 分析を行った結果を併 せて示す。EDS 分析の結果, 領域 $\mathrm{A}$ と Bからは $\mathrm{Al}, \mathrm{Cu}$ および $\mathrm{Mg}$ が検出され，それぞれの組成は $\mathrm{Al}-0.5 \mathrm{at} \% \mathrm{Cu}-0.5 \mathrm{at} \% \mathrm{Mg}$ と $\mathrm{Al}-1 \mathrm{at} \% \mathrm{Cu}-1 \mathrm{at} \% \mathrm{Mg}$ と見積もられ，いずれも母材の $\mathrm{Al}$ 相であ ることがわかる。高分解能 TEM像からも Alの格子が接合界 面で直接接触しており, ナノサイズの酸化物や異物を介さず に $\mathrm{Al}$ 相同士が接合されていることがわかる。つまり，電磁 圧接による両板の衝突時に板表面の酸化物や異物が板表面か ら金属ジェットとして排出されると同時に $\mathrm{Al}$ 相の新生面同 士の接合が行われたと考えられる。

\section{4 まとめ}

本研究では, 電磁圧接により 2000 系と 7000 系アルミニウ ム合金板の同種, または 6000 系アルミニウム合金板と鋼板 との異種金属板接合を行った。その結果，放電エネルギーの 増加または間隙長を広げ, 可動板の衝突速度を増加させるこ とで，いずれの接合も可能であった。比較的高い衝突速度で 接合した場合, 接合幅を広げることが可能であり, 両接合に おいて母材破断する強固な接合が可能である。また，接合界
面について組織観察を行った結果，接合界面では金属ジェッ 卜の排出による板の新生面同士での固相接合が行われ, 酸化 物や異物を介さずに $\mathrm{Al}$ 相同士が接合していた。これに加え, 波状模様形成によるアンカー効果や接合界面近傍での加工硬 化も観察され, これらの組成的要因が高い接合強度に寄与し ていると考えられる。

実用に用いられる $\mathrm{Al}$ 合金板や鋼板は純金属板と比較する と, 電磁圧接にとって比較的接合条件が狭い試料であるもの の, 接合が可能であることが明らかとなった。上記のように 電磁圧接の原理と特徵を理解し, 組織観察による接合メカ二 ズムの考察を深めることで, 今後, 電磁圧接における実用板 の高速固相接合の「接合指針」がより明確になると考えられ る。

\section{4. 外部熱源を用いたFSW（日本大学グループ）}

\section{1 背景と目的}

FSWにおけるPW とは欠陥のない接合を行うことができる 接合条件範囲を指し ${ }^{29)}$, 通常はこの範囲内から最適なツー ル回転数および接合速度の值が選択される。すなわち, ツー ルは「摩擦発熱による熱供給」と「素材の擋拌」という2つ の役割を担っており，PWはこれらの役割を同時かつ円滑に 果たすことができる範囲と言える。しかし，これらの役割 を同時に果たすことが求められることによって $\mathrm{PW}$ が狭くな り, 接合条件選定の自由度が低下する。この問題を解消する ためには, ツールの担う2つの役割を独立させることが有効 である。すなわち, 熱の供給を摩擦熱以外の外部熱源によっ て達成すれば, より広い範囲で回転数および接合速度を選択 できるようになる。 
外部熱源を用いる方法には，材料を直接加熱する方式と， 加熱されたツールを介して材料に熱を伝える方式がある。前

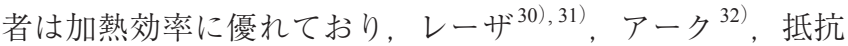
加熱 ${ }^{33)}$ などの熱源を用いてッール前方の材料を加熱するこ とによって，接合速度向上やッール負荷低減が可能であるこ とが報告されている。しかしながら、ッールから離れた位置 を加熱するため, 通常のFSW とはツール近傍の温度分布が 異なり，入熱量も大きくなるため熱影響部が拡大しやすい問 題がある。一方, 後者の加熱方法はほとんど報告例がないが, ツール直下の材料を加熱すると同時に擋挥することができ, 材料温度と変形特性に合った速度での擋挥を実現できると期 待される。また，FSW はシールドガスを必要としない接合 方法であることから，材料を水中で接合することも容易であ る。水中で接合することによって接合後の材料の泠却を促進 し, 熱影響部（HAZ）軟化と軟化域拡大を抑制することが できる。

以上の背景に基づき，本グループでは2つの課題に取り組 んだ。1つは補助加熱機構を備えたツールを用いた1050-H24 アルミニウム薄板の FSWである。この課題では $60 \mathrm{rpm}$ とい う著しく低いッール回転数で接合を試みた。もう1つの課題 は水中での1050-H24アルミニウム薄板の FSWである。これ らの課題に関する研究で解明された継手特性について以下に 詳述する。

\section{2 補助加熱機構を内蔵したツールを用いた 1050 アルミ ニウム薄板の摩擦攪汼接合}

厚さ $1 \mathrm{~mm}$ の1050-H24アルミニウム薄板同士の突合せ継手 をFSWにより作製した。使用したツールのショルダー径, ショルダー角, プローブ径，プローブ長はそれれそれ $9 \mathrm{~mm}, 4^{\circ}$, $3 \mathrm{~mm}, 0.7 \mathrm{~mm}$ である。プローブはねじを切っていない円柱 状とした。ッールはニクロム線ヒーターを内蔵しており, 通 電することによってショルダーおよびプローブを加熱でき る。このツールを $673 \mathrm{~K}$ に保った状態で回転数 $60 \mathrm{rpm}$, 前進 角 $3^{\circ}$ に設定し，接合速度を $0.5,1.0,1.5 \mathrm{~mm} / \mathrm{s}$ と変化させて 接合した。接合中の材料温度は, 突合せ面から前進側 (AS) および後退側（RS）にショルダー径に相当する $4.5 \mathrm{~mm}$ 離れ た位置の板厚中央に設置したK熱電対を用いて計測した。得 られた継手は，外観検査，巨視および微視的組織観察，マイ クロビッカース硬さ試験により評価した。

ッールのヒーターに通電しない状態で接合速度 $0.5 \mathrm{~mm} / \mathrm{s}$ の 接合条件にてFSWすると，材料の計測位置における温度は $349 \mathrm{~K}$ までしか上がらない。この温度は一般的なアルミニウ 厶合金のFSW と比較して著しく低い ${ }^{34)}$ 。このため, 継手表 面のビードは不規則な起伏を生じ，裏面には未接合部が存在 する。以上の結果から, 回転数 $60 \mathrm{rpm}$, 接合速度 $0.5 \mathrm{~mm} / \mathrm{s}$ は 入熱不足であり，健全な接合ができない PW 外の接合条件で あると判断できる。接合速度 1.0 抢よび $1.5 \mathrm{~mm} / \mathrm{s}$ の場合はさ らに入熱が減少するので, これらも同様に PW外となる。

補助加熱熱源を用いた状態で回転数 $60 \mathrm{rpm}$, 接合速度 $0.5 \mathrm{~mm} / \mathrm{s}$ の接合条件にて FSW した継手の断面巨視および微 視的組織を図18に示す。図18(a) の巨視的組織では，回転 数 $60 \mathrm{rpm}$ でも健全な継手を形成できていることがわかる。す なわち, 補助加熱熱源を使用することでPW を回転数 $60 \mathrm{rpm}$, 接合速度 $0.5 \mathrm{~mm} / \mathrm{s}$ まで拡大させることに成功した。また，図 には示さないが，この接合条件における計測位置での材料

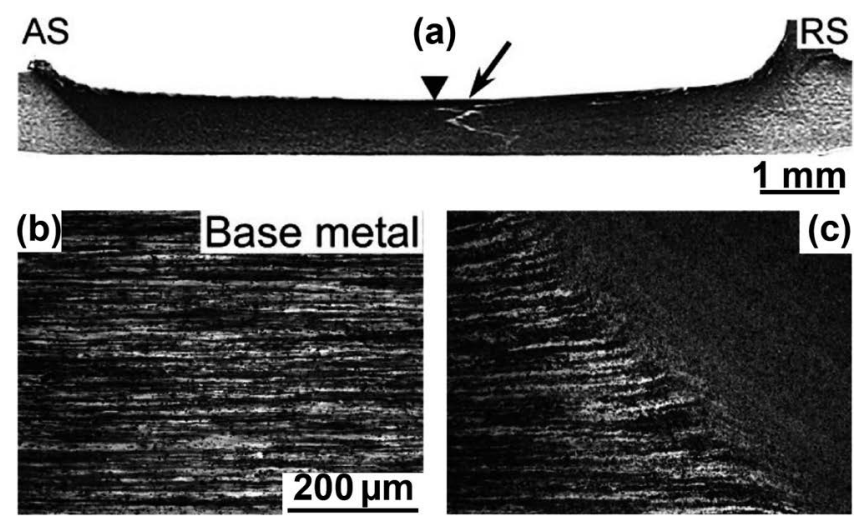

図18 補助加熱熱源を使用して $60 \mathrm{rpm}, 0.5 \mathrm{~mm} / \mathrm{s}$ にて接 合した継手横断面組織。(a) 継手全体の巨視的 組織，（b）母材の微視的組織，（c）ASの母材と SZの境界近傍の微視的組織

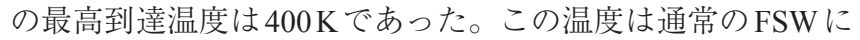
おいて健全な継手が得られる温度の下限よりも $60 \mathrm{~K}$ も低い。 このことから, 補助加熱熱源を使用して材料への入熱量を ツール回転数から独立させることによって, より低温で健全 な継手を形成可能となることが証明された。

このほか, 図18(a) にはッール加熱式FSWによって現れ た特徵が $2 つ$ 観察される。1つは矢印で示した明コントラス トが呈した組織が細く連続しているレイジーエスが継手中央 部のみに集中して観察されることである。レイジーエスが 継手中央部のみに集中した組織は, ッール回転軸まわりの 材料の塑性流動速度が板厚方向にほぼ一様であることを示 唆しており、これはさらに板厚方向の温度勾配が小さいこ とに起因すると考えられる。そしてもう1つは熱機械的影響 部（TMAZ）がほとんど観察されないことである。TMAZは 再結晶を生じない温度で塑性変形を受けた領域であることか ら, ツール加熱式FSWでは塑性変形が再結晶温度に達して いる領域のみに集中して生じていると考えられる。図18(c) に示す擋拌部（SZ）のAS端部近傍の微視的組織においても, 図 18(b) の母材に観察される典型的な圧延組織がTMAZに おいて板厚上方に曲げられることなく直接 SZに接している ことがわかる。SZの組織は再結晶により微細で等軸な整粒 組織を呈する。

図19は図18に示した継手の板厚中央部に扮ける接合部近 傍のマイクロビッカース硬さ分布である。この硬さ分布にお いて最も重要な点は，軟化域を生じていないことである。本 研究で使用した 1050 アルミニウム薄板はH 24 調質材であり この材料はFSW中の温度履歴によって HAZ, TMAZ, SZで構 成される継手領域全体が軟化することが知られている ${ }^{35)}$ 。 しかし，ッール加熱式FSWで作製した継手では，このよう な軟化域が形成されないのみならず，SZでは母材よりも硬 さが上昇しており，しかもその変化が急峻である。このこ とは, 低温, 低回転数での接合により, SZが強加工を経て 動的再結晶することによって組織が微細化するだけでなく, 個々の結晶粒内転位密度が高くなることを示している。ま た，図18において母材から HAZやTMAZを経ずに直接 SZ に接する継手組織とも合致している。以上のことから, 補助 加熱機構を用いて低回転数でFSWを行うことによって, 接 合部以外の組織を変化させずに接合することが可能となる。 


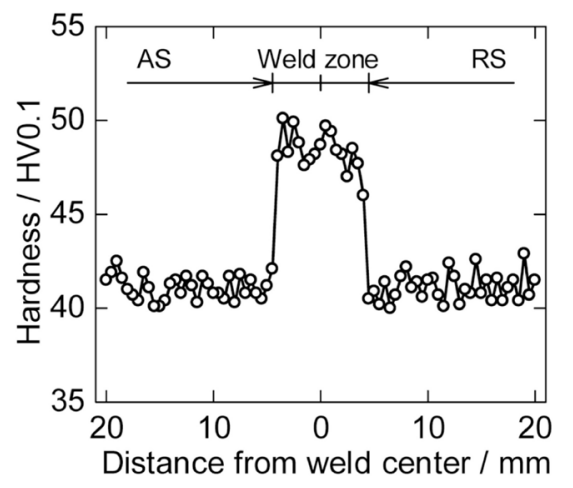

図 19 補助加熱熱源を使用して $60 \mathrm{rpm}, 0.5 \mathrm{~mm} / \mathrm{s}$ にて 接合した継手近傍の板厚中央におけるマイクロ ビッカース硬さ分布

\section{31050 アルミニウム薄板の水中FSW}

材料およびッール形状は前節に記載したものと同様とし て，ステンレス鋼製容器内に $298 \mathrm{~K}, 8 \times 10^{-3} \mathrm{~m}^{3}$ の水道水を満 たした中に材料を浸漬した状態で固定し，FSWした。ツー ル回転数は 1200 または $1800 \mathrm{rpm} の 2$ 通り選択し，それぞれに 対して接合速度を $20 \sim 40,20 \sim 80 \mathrm{~mm} / \mathrm{s}$ の範囲で変化させた。 接合中の温度計測, 継手評価方法も前節と同様とした。

各接合条件における材料温度計測位置での最高到達温度を ツールの回転ピッチ（接合速度をツール回転数で除した值） に対してプロットし，水中と大気中での FSWを比較する形 で図20に示す。水中で接合することによって材料からの抜 熱が促進され，同接合条件で空気中で接合した場合と比べて 最高到達温度が約 $40 \mathrm{~K}$ 低くなり，これは空気中での接合に おいてッール回転数を約 $2 / 3$ に低下させた接合条件に相当す る。空気中で接合した場合, 本研究で採用した全接合条件で 健全な継手が形成されるが，水中FSWの場合では $1800 \mathrm{rpm}$, $80 \mathrm{~mm} / \mathrm{s}$ の接合条件で継手底部が接合されないキッシングボ ンドが形成され，PWが低接合速度側へ縮小していることが 判明した。

材料の最高到達温度から $373 \mathrm{~K}$ までの冷却に要する時間か ら平均冷却速度を求め, ッールの回転ピッチに対してプロッ トしたグラフを図 21 に示す。全接合条件において水中FSW における材料の冷却速度は大気中FSWの2 倍超の高い值と なり，冷却が促進されていることがわかる。眓21からは以 上に加えて，冷却速度が接合䨌囲気（水中であるか大気中で あるか等）とッールの回転ピッチでほぼ一意的に決まること もわかる。

大気中でFSWした継手の接合部近傍のマイクロビッカー 久硬さは，例外なく母材よりも軟化した部位が存在する。 $1200 \mathrm{rpm}, 40 \mathrm{~mm} / \mathrm{s}$ の接合条件では SZの中央部では母材より も硬いが，AS およびRSのSZと母材の間には母材よりも硬 さが低下したHAZが形成される。その他の接合条件ではSZ も含めて母材よりも硬さが低下する。一方, 水中でFSW L た継手では， $1800 \mathrm{rpm}, 20 \mathrm{~mm} / \mathrm{s}$ （回転ピッチ $0.67 \mathrm{~mm} / \mathrm{r}$ ）の接 合条件を除いて，母材よりも硬さが低下した領域は形成され ていなかった。このことから，水中で接合することによって 接合中に高温で擋拌されている領域に隣接した材料の温度が 回復・再結晶を生じない温度に保持され, これら高温領域と 低温領域の境界部分の温度勾配が急峻となっていると考えら れる。

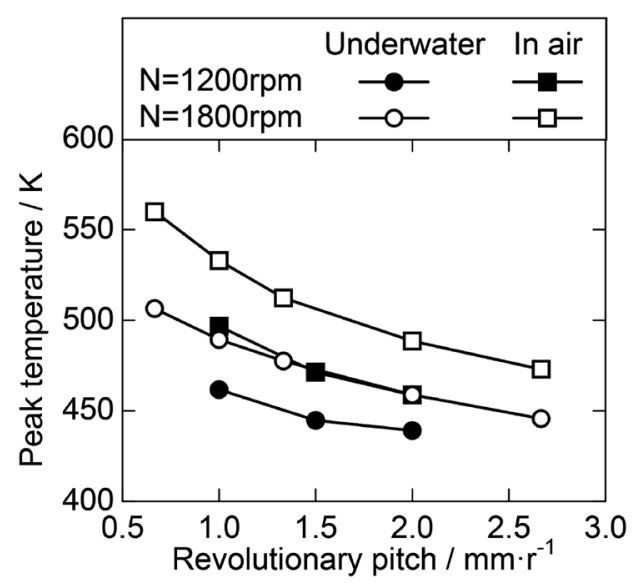

図20 水中および大気中 FSWにおける材料の最高到達 温度と回転ピッチの相関

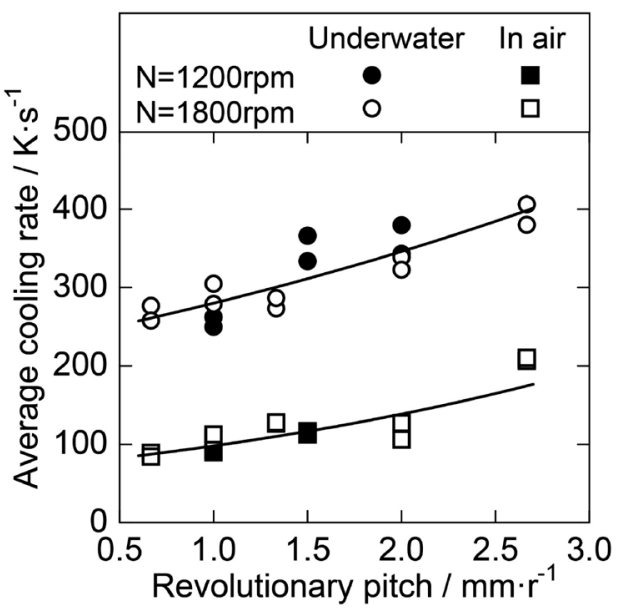

図21水中および大気中 FSWにおける材料の最高到達

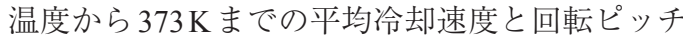
の相関

水中FSWには以上のような継手特性上の優位点のほか, ばりの形成を著しく抑制できるメリットがある。FSWにお けるばりは, 材料の撹拌流動域の上面側がッールのショル ダーで押さえている範囲よりも広がることによって形成され る。すなわち，材料を水中に浸漬した状態でFSWすること によって，擋拌流動域がショルダーの外まで広がることを抑 制できるのである。

\section{4 まとめ}

本研究によって, 補助加熱熱源を用いることで, ツールか ら摩擦発熱による熱供給の役割を軽減し，材料の温度に合わ せたツール回転数を選択できるようになる。これによって材 料流動を適切に制御し, 従来よりも低い温度でも欠陥のない 継手を形成できるようになる。これはPWが大きく広がるこ とと同義である。水中FSW も擋拌流動中の高温領域とその 他の領域の境界を狭くすることができる。この境界領域こそ が継手の機械的特性が最も低下する部位であるので, 継手特 性の向上を図ることができる。

本研究で検討から外した材料を直接加熱する外部加熱方式 を含めて, 材料の加工部位への熱の出入りを制御する技術は 組み合わせることができる。材料加工部近傍の温度場を適切 に制御することで，特性劣化や好ましくない界面反応を抑制 


\section{し，優れた特性を付与した継手の作製が可能となる。}

\section{5. おわりに}

ここでは，母材を溶融させることなく，短時間で強固な異 種金属接合を実現する爆発圧接, 電磁圧接, 摩擦攪拌接合等 の各種高速固相接合に関する研究成果を紹介した。3グルー プが共通の課題に取り組むことにより，高速固相接合に特有 の接合界面ならびにその近傍で生じる極短時間で生じる急速 加熱・急速冷却現象と, これに起因する接合界面の組織変化 や，接合メカニズムに関して多くの知見が得られた。本統合 的先端研究により得られた研究成果を，信頼性に富むアルミ ニウム合金同種・異種金属接合材を実現するための指導原理 として，多くの方々に活用していただければ幸いである。

なお，各研究グループにおける個別の研究遂行に加え， 3 グループでは，平成 28 年 3 月，平成 29 年 4 月に総合的先端研 究meeting（研究発表会兼研究室交流会）を開催し，3グルー プの教員と学生が一堂に会して最新の研究成果を発表すると ともに，実験設備等の見学や懇親会を実施してグループ間の 交流を深めることができた。これも統合的先端研究の貴重な 成果である。

謝 辞

本稿は，公益財団法人軽金属奨学会「統合的先端研究」と して平成 27 年から 2 年間の支援を受けて実施した研究成果の 一部をまとめたものです。本研究の遂行にあたり，軽金属奨 学会理事長をはじめ理事の方々には，多くの助言と激励をい ただきました。お荃様で研究室の学生諸氏の協力のもと研究 に励むことができました。ここに記して心より感謝の意を表 します。

\section{参 考 文 献}

1) M. Watanabe and S. Kumai: Mater. Trans., 50 (2009), 286-293.

2) M. Watanabe and S. Kumai: Mater. Trans., 50 (2009), 2035-2042.

3) M. Watanabe, S. Kumai, G. Hagimoto, Q. Zhang and K. Nakayama: Mater. Trans., 50 (2009), 1279-1285.

4) M. Watanabe and S. Kumai: Mater. Sci. Forum, 654-656 (2010), 755-758

5) M. Watanabe, S. Kumai and H. Kimura: Mater. Trans., 53 (2012), 951-958

6) S. Kakizaki, M. Watanabe and S. Kumai: Mater. Trans., 52 (2011), 1003-1008.
7) Y. Sawa, S. Kakizaki and S. Kumai: Proc. of ICAA13, (ISBN 978-1118-45804-4), Pittsburgh, USA June 3-7 (2012), 789-794.

8) 横山 隆: 衝撃工学の基礎と応用, 共立出版, (2014), 179181.

9）西脇淳人，相澤祐輔，原田陽平，熊井真次：スマートプロセス 学会誌, 4 (2015), 95-101.

10）西脇淳人，熊井真次：溶接学会論文集，34（2016），274-284

11) 西脇淳人, 熊井真次 : 溶接学会論文集, 35 (2017), 111-121.

12) K.-J. Lee, S. Kumai, T. Arai and T. Aizawa: Mater. Sci. Eng. A, 471 (2007), 95-101.

13) Y. Aizawa, J. Nishiwaki, Y. Harada, S. Muraishi and S. Kumai: J. Manuf. Process, 24 (2016), 100-106.

14) 熊井真次, 林田慶祐, 渡邊満洋：軽金属, 61 (2011), 206-212.

15）熊井真次, 林田慶祐：軽金属, 62（2012），331-337.

16）熊井真次，高谷謙斗：軽金属, 62 (2012), 293-299.

17) 高谷謙斗, 原田陽平, 熊井真次, 北山健二：軽金属, 62 (2012), 370-376.

18) Y. Harada, Y. Sada and S. Kumai: J. Manuf. Process, 23 (2016), 7582.

19) Y. Harada, Y. Sada and S. Kumai: J. Mater. Proc. Tech., 214 (2014), 477-484.

20）原田陽平，山田洋希，熊井真次：軽金属, 66（2016），489-496.

21) A. Leonardo and E. Dominique: J. Mater. Sci. Eng., 42 (2007), 42054214.

22) 浅倉太一, 原田陽平, 熊井真次：軽金属学会第 129 回秋期大会 講演概要, (2015), 227-228.

23) 特許：出願公告番号昭 35-11813.

24）溶接学会編：溶接・接合便覧，丸善，（2003），470-471.

25） 相沢友勝：塑性と加工, 41 (2000)， 265-267.

26）相沢友勝：塑性と加工, 44 (2003)，957-959.

27) 系井貴臣, 井上祥一, 岡川啓悟：軽金属, 67（2017）， 8-15.

28) H. K. Wylie, P. F. G. Williams and B. Crossland: Proc. 3rd Int. Conf. of the Center for High Energy Rate Forming, Denver Research Institute, Denver, CO, (1971), 1.3.1-1.3.43.

29）溶接学会編：摩擦攪拌接合一FSWのすべて一, 産報出版, (2006), $18-21$.

30) G. Kohn, Y. Greenberg, I. Makover and A. Munitz: Weld. J., 81-2 (2002), 46-48.

31) Y. F. Sun, Y. Konishi, M. Kamai and H. Fujii: Mater. Des., 47 (2013), 842-849.

32) H. S. Bang, H. S. Bang, G. H. Jeon, I. H. Oh and C. S. Ro: Mater. Des., 37 (2012), 48-55.

33) T. G. Santos, R. M. Miranda and P. Vilaça: J. Mater. Process. Technol., 214 (2014), 2127-2133.

34) S. Mironov, K. Inagaki, Y. S. Sato and H. Kokawa: Metall. Mater. Trans., A, 46A (2015), 783-790.

35) H. Liu, M. Maeda, H. Fujii and K. Nogi: J. Mater. Sci. Lett., 22 (2003), 41-43. 